\title{
Osteolytic effects of tumoral estrogen signaling in an estrogen receptor-positive breast cancer bone metastasis model
}

\author{
Julia N. Cheng ${ }^{1}$, Jennifer B. Frye ${ }^{2}$, Susan A. Whitman², Andrew G. Kunihiro³, Julia A. Brickey², Janet L. \\ Funk $^{2,3}$ \\ ${ }^{1}$ Cancer Biology Graduate Interdisciplinary Program, University of Arizona, Tucson, AZ 85724, USA. \\ ${ }^{2}$ Department of Medicine, University of Arizona, Tucson, AZ 85724, USA. \\ ${ }^{3}$ Department of Nutritional Sciences, University of Arizona, Tucson, AZ 85724, USA
}

Correspondence to: Prof. Janet L. Funk, Department of Medicine, University of Arizona, P.O. Box 24-5218, Tucson, AZ 85724, USA.E-mail: jfunk@email.arizona.edu

How to cite this article: Cheng JN, Frye JB, Whitman SA, Kunihiro AG, Brickey JA, Funk JL. Osteolytic effects of tumoral estrogen signaling in an estrogen receptor-positive breast cancer bone metastasis model. J Cancer Metastasis Treat 2021;7:17.

https://dx.doi.org/10.20517/2394-4722.2021.27

Received: 30 Jan 2021 First Decision: 1 Mar 2021 Revised: 11 Mar 2021 Accepted: 18 Mar 2021 Available online: 8 Apr 2021

Academic Editors: Robert Coleman, Lucio Miele Copy Editor: Xi-Jun Chen Production Editor: Xi-Jun Chen

\begin{abstract}
Aim: Estrogen receptor $\alpha$-positive (ER+) subtypes of breast cancer have the greatest predilection for forming osteolytic bone metastases (BMETs). Because tumor-derived factors mediate osteolysis, a possible role for tumoral ER $\alpha$ signaling in driving ER+ BMET osteolysis was queried using an estrogen $\left(E_{2}\right)$-dependent $E R+$ breast cancer BMET model.

Methods: Female athymic Foxn $1^{\text {nu }}$ mice were inoculated with human ER+ MCF-7 breast cancer cells via the left cardiac ventricle post- $E_{2}$ pellet placement, and age- and dose-dependent $E_{2}$ effects on osteolytic ER+ BMET progression, as well as direct bone effects of $\mathrm{E}_{2}$, were determined.

Results: Osteolytic BMETs, which did not form in the absence of $E_{2}$ supplementation, occurred with the same frequency in young (5-week-old) vs. skeletally mature (16-week-old) $E_{2}(0.72 \mathrm{mg})$-treated mice, but were larger in young mice where anabolic bone effects of $E_{2}$ were greater. However, in mice of a single age and across a range of $E_{2}$ doses, anabolic $E_{2}$ bone effects were constant, while osteolytic $E R+B M E T$ lesion incidence and size increased in an $E_{2}$ dose-dependent fashion. Osteoclasts in $E R+$ tumor-bearing (but not tumor-naive) mice increased in an $E_{2}-$ dose dependent fashion at the bone-tumor interface, while histologic tumor size and proliferation did not vary with $E_{2}$ dose. $E_{2}$-inducible tumoral secretion of the osteolytic factor parathyroid hormone-related protein ( $\left.P T H r P\right)$ was dose-dependent and mediated by $E R \alpha$, with significantly greater levels of secretion from ER+ BMET-derived tumor
\end{abstract}


cells.

Conclusion: These results suggest that tumoral ER $\alpha$ signaling may contribute to ER+ BMET-associated osteolysis, potentially explaining the greater predilection for ER+ tumors to form clinically-evident osteolytic BMETs.

Keywords: Breast cancer, estrogen receptor, bone metastasis, estradiol, osteolysis, osteoclasts, parathyroid hormone-related protein, bone

\section{INTRODUCTION}

Breast cancer is the most common female cancer in the world and the 2nd leading cause of cancer mortality ${ }^{[1]}$. The majority of women with metastatic breast cancer have bone metastases (BMETs), which are primarily osteolytic ${ }^{[2,3]}$. Eighty percent of women with breast cancer BMETs have ER+ tumors due to both the higher incidence of this subtype and its 2 -fold greater proclivity to form metastases in bone ${ }^{[4]}$. This association of BMETs in metastatic breast cancer with tumoral ER $\alpha$ expression, which remains highly concordant between primary and bone metastatic tumors ${ }^{[5-7]}$, introduces the possibility that tumor cell ER $\alpha$ signaling within the bone milieu, independent of proliferative effects that are important but not site-specific, may also be driving tumor-associated osteolysis, which is bone-specific, known to be dependent on tumorderived factors ${ }^{[8-11]}$, and of clear clinical relevance due to the morbidity and mortality associated with osteolytic ER+ BMETs. However, a specific role for ERa signaling in driving tumor-induced osteolysis in ER+ BMET has not, to our knowledge, been previously investigated. Given the frequent association of ER $\alpha-$ positivity with BMETs, this question is highly relevant for the management of breast cancer, particularly since many ER+ BMETs occur post-hormone therapy (HT) and/or are associated with ligand-independent activating ER mutations ${ }^{[12,13]}$. If tumoral $\mathrm{E}_{2}$ signaling contributes to ER+ BMET progression by driving tumor-associated osteolysis, targeting of specific downstream signaling pathways mediating this effect could provide novel molecular approaches for skeletal therapeutics to block BMET progression for ER+ tumors.

Because mice, unlike humans, lack aromatase expression in mammary tissue and bone cells ${ }^{[14,15]}$ and also have 10-fold lower circulating $17 \beta$-estradiol $\left(\mathrm{E}_{2}\right)$ levels than humans ${ }^{[16]}$, the optimal growth of human ER+ breast cancer orthotopic tumors and osteolytic BMETs in preclinical murine models is dependent on exogenous $\mathrm{E}_{2}$ supplementation ${ }^{[17,18,19-26,27,28]}$. This presents a challenge when studying murine models of human ER+ BMETs given the responsiveness of both tumor and bone cells to $\mathrm{E}_{2}^{[29-33]}$ and the absence of syngeneic models of murine ER+ breast cancer BMET. Indeed, the $\mathrm{E}_{2}$ doses required to promote $\mathrm{ER}+$ breast cancer growth in osteolytic xenograft models also increase murine bone mass ${ }^{[18,20,21,26,28,34]}$ and furthermore, can induce osteolytic murine osteosarcomas in some animals, as previously demonstrated by our laboratory ${ }^{[34]}$.

Evidence from ER-BMET models, which represent the majority of preclinical breast cancer BMET research, has allowed for an assessment of the influence of estrogenic effects on the bone microenvironment, independent of tumor cell ER signaling, on osteolytic ER- BMET progression. Taken together, these ERbreast cancer xenograft studies suggest that both induction of bone formation by $\mathrm{E}_{2}$-treatment ${ }^{[3,36]}$ and bone resorption by $\mathrm{E}_{2}$-deprivation [via ovariectomy $\left.(\mathrm{OVX})\right]^{[28,37,38]}$ promote ER- BMET progression. In ER+ BMET models, $\mathrm{E}_{2}$ bone-microenvironmental effects have often not been considered ${ }^{[19,21-26,39,40]}$ and are rarely documented ${ }^{[18,20,28]}$, while a role of tumor ER $\alpha$ signaling in driving tumor-associated osteolysis has not, to our knowledge, previously been studied.

To address these knowledge gaps regarding the effects of ER $\alpha$ signaling in the tumor itself $v s$. the bone microenvironment in driving tumor-associated osteolysis and osteolytic progression for ER+ BMET, $\mathrm{E}_{2}$ 
effects were assessed in a murine model of osteolytic ER+ BMET using intracardiac (IC) injection of ER+ human breast cancer cells. Studies included an exploration of dose- and age-dependent effects of $\mathrm{E}_{2}$ with the goal of identifying conditions under which $\mathrm{E}_{2}$ effects on bone turnover could be accounted for separately from direct effects of $E_{2}$ on ER+ tumor-mediated osteolysis. The primary objective of these studies was to determine whether tumoral ER $\alpha$ signaling, in addition to well-known proliferative effects that are not sitespecific, could be driving osteolysis within the bone microenvironment, thus potentially explaining the greater proclivity of ER+ (vs. ER-) breast cancer cells to form clinically evident osteolytic BMET.

\section{METHODS}

\section{Cell lines and culture}

Human ER+ breast cancer tumor cell lines, MCF-7, T47D, and ZR-75-1 [American Type Culture Collection (ATCC), Manassas, VA], or bone-tropic ER- human MDA-MB-231 (MDA-SA) cells ${ }^{[41,42]}$, generously provided by Dr. Theresa Guise, were cultured in $\mathrm{E}_{2}$-replete Dulbecco's modified Eagle's medium (DMEM; Invitrogen, Carlsbad, CA) or RPMI-1640 (Invitrogen), as per ATCC's recommendation, containing 10\% of heat-inactivated fetal bovine serum (FBS; Atlanta Biologicals, Flowery Branch, GA), 1\% of penicillin/streptomycin (Thermo Fisher, Waltham, MA) in $37{ }^{\circ} \mathrm{C}$, and $5 \%$ of $\mathrm{CO}_{2}$ in a humidified atmosphere. All human cell lines were authenticated, as previously described ${ }^{[41,43]}$, including MCF-7 BMETderived tumor cells used in parathyroid hormone-related protein ( $\mathrm{PTHrP}$ ) secretion experiments, which were isolated from osteolytic BMET-bearing limbs $42-56$ days post-inoculation and passaged twice to remove non-immortalized and non-adherent murine cells prior to authentication.

\section{Animal studies}

All animal protocols were approved by the Institutional Animal Care and Use Committee at The University of Arizona (UA) in accordance with the National Institutes of Health Guide for the Care and Use of Laboratory Animals. Four or 15-week-old female Foxn $1^{n u}$ athymic nude outbred mice (Envigo, Indianapolis, IN) were received and housed in plastic cages (maximum 5/cage) in laminar flow isolated hoods with ad libitum access to water and autoclaved mouse chow (NIH-31 Modified diet, Envigo). The number of animals required was determined a priori with the statistical goal of detecting a significant difference of osteolytic lesion area between groups assuming a moderate effect size with $\alpha=0.05$ and $\beta=0.80$ ( $G^{\star}$ Power Software v3.1 $)^{[4]}$. Mice $\left(n=8\right.$-13/group) were inoculated at approximately 5 - or 16 -week of age with $1 \times 10^{5}$ human breast cancer cells (MCF-7, MDA-SA, T47D, or ZR-75-1) via the left cardiac ventricle (IC), as previously described ${ }^{[4] 1}$, either in estrogen-naive mice, or in estrogen-supplemented mice 3 days postplacement of 60-day extended-release $17 \beta$-estradiol $\left(E_{2}\right)$ pellets $(0.05,0.10,0.18,0.36$, or $0.72 \mathrm{mg}$, Innovative Research of America, Sarasota, FL $)^{[34]}$. In separate experiments, as indicated, mice not inoculated with tumor cells (tumor-naive) were similarly treated with $\mathrm{E}_{2}$ pellets to determine effects on bone turnover independent of tumor-associated osteolysis. Additionally, to examine the possible influence of $\mathrm{E}_{2}$ supplementation on tumor cell dissemination to bone, mice 3 -days post- $\mathrm{E}_{2}$ pelleting ( $v s$. controls, $n=3$-5/group) were inoculated with $8 \times 10^{5}$ MCF-7 cells freshly labeled with Vybrant DiD, as per the manufacturer's instructions (Thermo Fisher), with fluorescent membrane staining remaining detectable for up to 7 days in culture. Twenty-four hours post-inoculation, cells were isolated from each proximal (25\%) tibia, the most common and earliest site of BMET (data not shown), by flushing with media and repeated washing and crushing of bone. Cells thus isolated were seeded into 48 -well cell-culture plates ( 3 wells/tibia) and allowed to adhere overnight prior to imaging of DiD-positive cells using the Cy5 filter of a Keyence BZ-X700 fluorescent microscope (Keyence Corporation of America, Itasca, IL). DiD-positive (DiD+) tumor cells, quantified using ImageJ software (National Institutes of Health, NIH), are reported as DiD+ cells $/ 10^{6}$ bone marrow cells for each tibia. Similarly isolated cells from tumor-naive mice were included as negative controls, and cultured MCF-7 cells 24 h-post DiD labeling were used as positive microscopy controls. No changes in health status necessitating euthanasia occurred in mice, which were also examined 6-week post- 
tumor cell inoculation at gross necropsy for non-bone metastases, as determined by researchers and UA veterinary staff: rare unanticipated deaths were attributable to anesthesia, weights were unchanged in $\mathrm{E}_{2}-$ treated and/or tumor-bearing mice $v s$. controls, and urinary retention, a well-characterized side-effect of $\mathrm{E}_{2}-$ supplementation in mice ${ }^{[45,46]}$ that was not severe enough to warrant early termination, was observed in $20 \%$ $30 \%$ of mice treated with higher $\mathrm{E}_{2}$ doses, as previously reported ${ }^{[34]}$.

\section{Radiographic determination of osteolytic BMET lesions and $E_{2}$ effects on bone}

To assess the size and incidence of radiographically-evident osteolytic BMET lesions, radiographs of mouse hind limbs (Faxitron UltraFocus 1000, Faxitron Bioptics, Tucson, AZ) in $\mathrm{E}_{2}$-supplemented tumor cellinoculated mice were obtained weekly over the 6-week course of experiments. Radiographic osteolytic lesion incidence and area per mouse were determined in a blinded fashion with radiographic images assessed by three independent investigators using ImageJ software $(\mathrm{NIH})^{[34]}$. Because $\mathrm{E}_{2}$ can induce osteolytic osteosarcomas in nude mice ${ }^{[34]}$, the identity of osteolytic BMETs in $\mathrm{E}_{2}$-supplemented mice was verified by correlating radiographic lesions in each hind limb bone with histologic evidence of cytokeratinpositive breast cancer tumors ${ }^{[20,34]}$ prior to calculating radiographic osteolytic BMET incidence or lesion area per mouse. When calculating average osteolytic lesion size, mice lacking osteolytic BMET were excluded so that $\mathrm{E}_{2}$ effects on lesion size could be assessed independent of effects on incidence. In parallel experiments to determine $\mathrm{E}_{2}$ effects on bone in the absence of osteolytic BMET, dual-energy X-ray absorptiometry (DXA) was performed weekly in $\mathrm{E}_{2}$-supplemented mice not inoculated with tumor cells (tumor naive) to assess changes in tibial areal bone mineral density (aBMD) (Faxitron UltraFocus 1000) ${ }^{[34]}$. At termination of these 6-week experiments, to examine $\mathrm{E}_{2}$ effects specific to trabecular bone, microcomputed tomography (microCT) imaging was performed ex vivo in a subset of mice to assess proximal tibial metaphyseal trabecular bone volume/total volume (BV/TV) by the Endocrine Research Unit at the San Francisco VA Medical Center (Scanco microCT 50, Scanco Medical, Basserdorf, Switzerland) as previously described ${ }^{[34,4]}$.

\section{Bone metastatic breast cancer tumor histology and bone histomorphometry}

Hind limbs were removed either 2 weeks (bone histomorphometry) or 6 weeks (bone histomorphometry or immunohistochemical analysis of Ki67, ER, or cytokeratin) post-tumor cell inoculation, fixed, decalcified, and paraffin-embedded for histologic analyses of midsagittal (approximate depth of 400-500 $\mu \mathrm{M}$ ) 5-6 $\mu \mathrm{M}$ sections as previously described ${ }^{[48]}$. For measuring histologic breast cancer tumor size (tumor burden), epithelial MCF-7 breast cancer tumors were identified using a pan-cytokeratin primary antibody (\#Z0622, Agilent Dako, Santa Clara, CA) and continued expression of ER $\alpha$ was verified using a human ER $\alpha$ primary antibody (\#ab108398, Abcam, Cambridge, United Kingdom) using previously described immunohistochemical (IHC) methods ${ }^{[48]}$. Cytokeratin-positive breast cancer tumor area in hind limbs bones was determined in a blinded fashion (expressed per leg as \% of tumor area/bone area). Proliferating breast cancer cells in bone were identified using a primary antibody directed against a human Ki67 proliferation marker (\#D2H10, Cell Signaling, Danvers, MA). Breast cancer tumor cell proliferation in each hind limb was assessed in a blinded fashion by calculating the average number of Ki67-positive tumor cells in four high power fields per bone (expressed per hind limb as \% of total tumor cells), with the mean for each treatment group determined by averaging values for each limb. In addition, osteoblasts-identified as hematoxylin-stained mononuclear cuboidal cells lining the bone surface-or multinucleated tartrate-resistant acid phosphatase (TRAP)-positive osteoclasts were quantified in the tibial metaphyses of tumor-naive mice or at the bone tumor interface of tumor-bearing mice, as per ASBMR nomenclature Committee Guidelines and using standard methods, as previously described ${ }^{[34,41,49-53]}$. Osteoclasts or osteoblasts in tumor-naive mice are reported as cell number per $\mathrm{mm}$ of bone surface (BS) or per tissue area $\left(\mathrm{mm}^{2}\right)$, and osteoclasts in tumorbearing hind limbs of mice are reported as cell number per $\mathrm{mm}$ of bone at the tumor-bone interface ${ }^{[34,41,49,54,55]}$. All images for immunohistology and bone histomorphometry were analyzed using ImageJ software (NIH). 


\section{Serum markers of bone turnover or estradiol}

Serum markers of bone formation [rat/mouse P1NP EIA; Immunodiagnostic Systems (IDS), United Kingdom] or bone resorption (mouse CTX-1; IDS) were measured in fasting serum collected 2 weeks after the start of $\mathrm{E}_{2}$ supplementation ( $v s$. age-matched controls) using commercially available ELISA kits ${ }^{[1,28]}$ as previously described ${ }^{[34]}$. $\mathrm{E}_{2}$ levels in serum collected 2 weeks post pellet placement were assayed by the University of Virginia Center for Research in Reproduction Ligand Assay and Analysis Core using a commercially available $17 \beta$-estradiol ELISA developed for use in mice (Calbiotech, El Cajon, CA) ${ }^{[56]}$. All sera were stored at $-80^{\circ} \mathrm{C}$ prior to assay.

\section{PTHrP assay}

To analyze PTHrP secretion from ER+ tumor cells and its $\mathrm{E}_{2}$ dependency, ER+ MCF-7 cells or ER+ tumor cells isolated from MCF-7 BMET were plated in 24-well plates at a density of $1.3 \times 10^{5}$ cells/well in $\mathrm{E}_{2}$ depleted media [phenol red-free DMEM (Invitrogen), 10\% charcoal-stripped FBS (Valley Biomedical, Winchester, VA), 1\% penicillin/streptomycin (Thermo Fisher), and $200 \mathrm{mM} \mathrm{L-Glutamine} \mathrm{(Sigma} \mathrm{Aldrich,}$ St. Louis, MO)] for 4 days, during which time cell number did not change for any cell line (data not shown), prior to treatment with $\mathrm{E}_{2}\left(10^{-11}-10^{-6} \mathrm{M}\right.$, as indicated; Sigma Aldrich), an ER a specific agonist propyl pyrazole triol (PPT; $10^{-8} \mathrm{M}$; Tocris, Minneapolis, MN), an ER $\alpha$ specific antagonist methyl-piperidinopyrazole hydrate (MPP; $10^{-6} \mathrm{M}$, Tocris), or vehicle control for 48 or $52 \mathrm{~h}$, as indicated. Conditioned media, stored at $-80{ }^{\circ} \mathrm{C}$ after addition of protease inhibitors (Sigma Aldrich), were assayed for secreted PTHrP using a commercial immunoradiometric assay (Beckman Coulter, Brea, CA). A lack of treatment effect on cell number during the 48 or 52-h incubation was verified using a commercial MTT assay (ATCC).

\section{Statistical analyses}

Unless otherwise noted, data are reported as mean \pm SEM, with statistical significance of 2 -sided $P$-values defined as $P \leq 0.05$. Statistical differences were determined using Prism 8.0 software (Graphpad, San Diego, CA) for 1- or 2-way analyses of variance (ANOVA) with post-hoc testing as well as tests for log-rank, mixed-effects, and $t$-test, as indicated. Analyses of skeletal parameters in tumor naive mice were not corrected for multiple comparisons, using Fisher's LSD test, to maximize the possibility of detecting dosedependent $\mathrm{E}_{2}$ effects (although none were found) ${ }^{[57]}$.

\section{RESULTS}

\section{$E_{2}$-dependent osteolytic ER+ MCF-7 BMET progression in young vs. skeletally mature $E_{2}(0.72 \mathrm{mg})$ - supplemented mice}

Osteolytic BMETs were not detected in the absence of $\mathrm{E}_{2}$ supplementation when young (5-week-old) mice inoculated with MCF-7 cells were followed for up to 8 months (data not shown). When supplemented with an $\mathrm{E}_{2}$ dose $(0.72 \mathrm{mg})$ supporting in vivo MCF-7 orthotopic tumor growth ${ }^{[17,58]}$, radiographic osteolytic breast cancer lesions were evident as early as 2 weeks post-MCF-7 tumor cell inoculation of young (5-week old) mice (Figure $1 \mathrm{~A}$ and inset), reaching a maximal incidence of $69 \%$ within 4 weeks with continuous size increases over the 6-week course of the experiment [Figure 1B], without evidence of metastases at non-bone sites. BMET formation in $\mathrm{E}_{2}(0.72 \mathrm{mg})$-supplemented MCF-7-inoculated mice contrasted with results in 5week-old mice inoculated with T47D or ZR-75-1 cells, where no osteolytic BMETs were noted (data not shown). When skeletally mature (16-week-old) mice supplemented with the same $0.72 \mathrm{mg} \mathrm{E}_{2}$ dose were inoculated with MCF-7 cells, the progression time course and incidence of osteolytic BMET lesion formation were the same as those in 5 -week mice [Figure $1 \mathrm{~A}$ ]; however, osteolytic lesion size was significantly smaller [Figure 1B]. Radiographs documenting proximal tibial and distal femoral osteolytic lesions, also common sites for ER- BMETs ${ }^{[59]}$, were also notable for clear evidence of $\mathrm{E}_{2}$-driven, albeit possibly differential, increases in bone density in mice of both ages [Figure $1 \mathrm{C}$ ]. This observation raised questions about possible contributions of $\mathrm{E}_{2}$ effects on the bone microenvironment ( $v$ s. direct effects on ER+ 

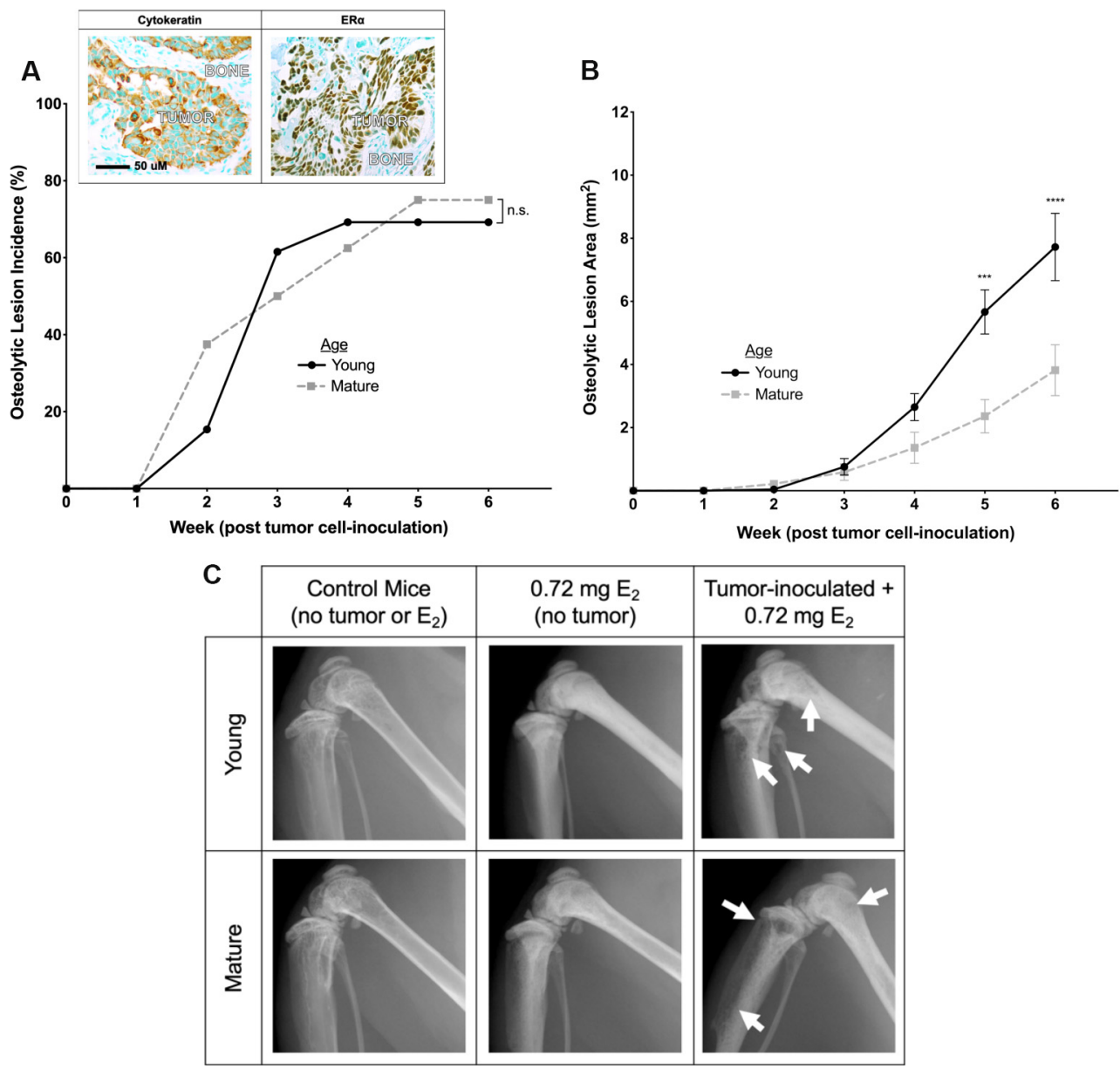

Figure 1. Comparison of osteolytic ER+ BMET progression in young vs. skeletally mature mice supplemented with $0.72 \mathrm{mg} \mathrm{E}_{2}$. (A) Osteolytic lesion incidence and (B) osteolytic lesion area in young (5-week-old) and skeletally mature (16-week-old) mice supplemented with $0.72 \mathrm{mg} \mathrm{E}_{2}$ and inoculated with $\mathrm{ER}+$ tumor cells $(n=8-13$ /group). Inset, representative immunohistochemical (IHC) images demonstrating cytokeratin+ (left panel; brown), ER $\alpha+$ (right panel; brown) human breast cancer tumors in tibiae. ${ }^{\star \star \star} P \leq 0.001$, ${ }^{\star \star \star \star \star} P \leq 0.0001$ young vs. skeletally mature mice, by 2 -way ANOVA with Sidak's post-test. There was no significant difference (n.s.) in osteolytic lesion incidence by Log-rank (Mantel-Cox) test. (C) Representative hind limb radiographs in young (top) vs. mature (bottom) age-matched control (left panels), naive $E_{2}\left(0.72 \mathrm{mg}\right.$ )-supplemented (middle panels), or tumor cell-inoculated and $\mathrm{E}_{2}(0.72 \mathrm{mg})$ supplemented mice (right panels) 6 weeks post-inoculation and $\mathrm{E}_{2}$ supplementation. Osteolytic lesions are marked by arrows.

tumors) in supporting ER+ MCF-7 BMET progression, a postulate further supported by findings in 5-weekold mice inoculated instead with osteotropic ER-MDA-MB-231 cells, where treatment with the same 0.72 $\mathrm{mg} \mathrm{E}_{2}$ dose led to an increase in osteolytic lesion size ( $3.5 \pm 0.8$-fold increased lesion size in $\mathrm{E}_{2}$-supplemented $(n=12) v s$. control mice $(n=10), P<0.01)$, but unchanged incidence $(91.6 \% v s .80 .0 \%, P>0.05)$, consistent with prior reports of pro-metastatic, anabolic $\mathrm{E}_{2}$ bone effects in ER- BMET models $s^{[35,36]}$.

\section{Differential effects of $E_{2}(0.72 \mathrm{mg})$ on bone turnover in tumor-naive young vs. skeletally mature mice}

Because radiographs suggested that anabolic effects of $E_{2}(0.72 \mathrm{mg})$ on bones in tumor-bearing mice could be age-dependent, direct bone effects of this $\mathrm{E}_{2}$ dose $(0.72 \mathrm{mg})$ were quantified in tumor-naive mice of both ages to assess the postulate that $\mathrm{E}_{2}(0.72 \mathrm{mg})$-driven $\mathrm{ER}+\mathrm{BMET}$ osteolytic lesion size was greater in mice whose bones yielded a greater anabolic $\mathrm{E}_{2}$ response (i.e., young mice). Total tibial aBMD increased significantly in response to $\mathrm{E}_{2}(0.72)$ over 6 weeks of supplementation in tumor-naive mice of both ages [Figure 2A], but with a larger increase in younger mice (68\%vs. 23\%), whose BMD was lower at baseline and still increasing in untreated age-matched controls. Cross-sectional microCT images [Figure 2B] 

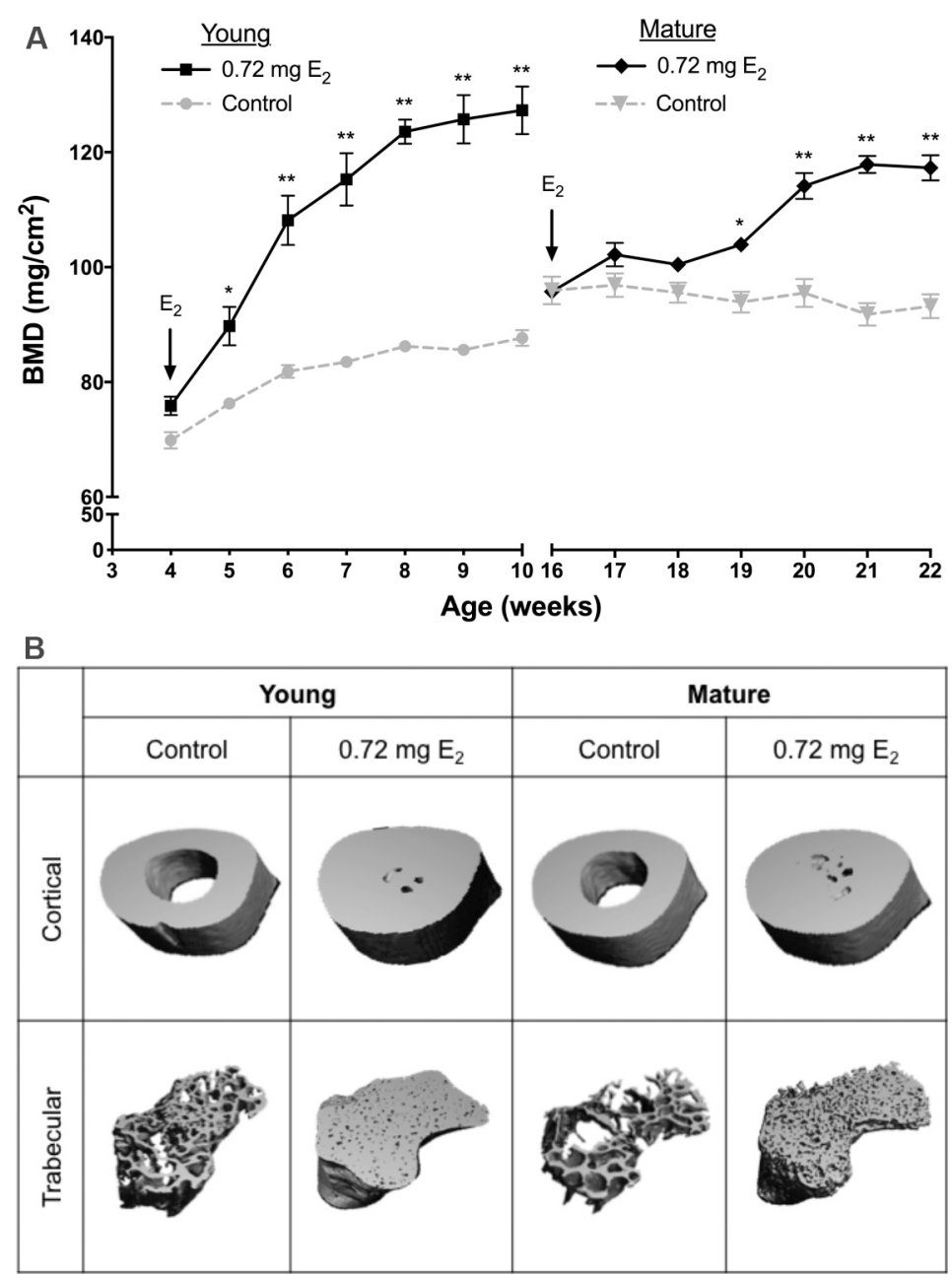

Figure 2. Effects of $0.72 \mathrm{mg} \mathrm{E}_{2}$ on bone mineral density and structure in tumor-naive young vs. skeletally mature mice. (A) Tibial areal bone mineral density (BMD) in young (4-week-old) vs. skeletally mature (15-week-old) mice supplemented with $0.72 \mathrm{mg} \mathrm{E}_{2}$ (vs. control), as measured by DXA ( $n=6-8 /$ group). Arrows indicate time of $E_{2}$ pellet placement. ${ }^{\star} P \leq 0.01,{ }^{\star \star} P \leq 0.0001$ vs. age-matched control, by 2-way ANOVA with Sidak post-test. (B) Representative microCT images of tibial cortical (top) and trabecular (bottom) bone of young vs. skeletally mature $E_{2}(0.72 \mathrm{mg})$-supplemented mice (vs. age-matched controls), 6 weeks after $E_{2}$ pellet placement.

confirmed dramatic, but differential, effects of $\mathrm{E}_{2}$ on both cortical and trabecular bone in the tibiae of skeletally young $v s$. mature mice after 6 weeks of treatment. In the proximal tibial, a frequent osteolytic BMET site, aBMD and trabecular BV/TV increased significantly in response to $\mathrm{E}_{2}$ in mice of both ages [Table 1]; however, the increase was significantly greater in young mice [e.g., BV/TV of $91 \%$ ss. $60 \%(P<$ 0.0001 ) in young $v s$. mature, respectively].

In skeletally mature mice, P1NP, a serum marker of bone formation, was significantly lower ( $v s$. young mice) and unchanged by $0.72 \mathrm{mg} \mathrm{E}_{2}$-supplementation, contrasting with a $0.72 \mathrm{mg} \mathrm{E}_{2}$-induced increase in already significantly higher P1NP levels in young mice, such that P1NP levels were 3.1-fold higher $(P<$ $0.0001)$ in $\mathrm{E}_{2}$-treated young $v$ s. skeletally mature mice [Table 1]. Osteoblast number (N.Ob) per bone surface tended to increase in response to $\mathrm{E}_{2}$ treatment in mice of both ages; however, these trends were not statistically significant. Given the large increase in bone surface, N.Ob per area was also calculated and was only significantly increased in response to $\mathrm{E}_{2}$ in young mice, resulting in $\mathrm{Ob}$ counts that were 1.6-fold higher in young ( $v s$. mature) $\mathrm{E}_{2}$-treated mice $(P<0.05)$, consistent with higher circulating P1NP levels [Table 1]. 
Table 1. $E_{2}$ effects on bone parameters in young and mature tumor-naive mice (mean $\left.\pm \mathrm{SEM}\right)^{\mathrm{a}}$

\begin{tabular}{|c|c|c|c|c|c|c|c|c|c|c|c|}
\hline & \multicolumn{6}{|c|}{ Young (4-week-old) } & \multicolumn{3}{|c|}{ Mature (15-week-old) } & \multirow{2}{*}{\multicolumn{2}{|c|}{$\begin{array}{c}\text { Young vs. Mature } \\
\text { P-values }\end{array}$}} \\
\hline & \multicolumn{3}{|c|}{ Mean (SEM) } & \multicolumn{3}{|c|}{ P-values } & \multicolumn{2}{|c|}{ Mean (SEM) } & \multirow{2}{*}{$\begin{array}{l}\text { P-values } \\
\text { Control } \\
\text { vs. } E_{2} 0.72 \\
\text { mg } \\
\end{array}$} & & \\
\hline & Control & $\begin{array}{l}E_{2 \prime} \\
0.05 \\
m g \\
\end{array}$ & $\begin{array}{l}E_{2 \prime} \\
0.72 \\
m g \\
\end{array}$ & $\begin{array}{l}\text { Control } \\
\text { vs. } \mathrm{E}_{2} 0.05 \\
\mathrm{mg}\end{array}$ & $\begin{array}{l}\text { Control } \\
\text { vs. } E_{2} 0.72 \\
\mathrm{mg}\end{array}$ & $\begin{array}{l}E_{2} 0.05 \\
\mathrm{mg} \text { vs. } \\
0.72 \mathrm{mg}\end{array}$ & Control & $\begin{array}{l}E_{2 \prime} \\
0.72 \\
m g \\
\end{array}$ & & $\begin{array}{l}\text { Control, } \\
\text { Young vs. } \\
\text { Mature }\end{array}$ & $\begin{array}{l}\mathrm{E}_{2} 0.72 \mathrm{mg}, \\
\text { Young vs. } \\
\text { Mature }\end{array}$ \\
\hline \multicolumn{12}{|c|}{ Proximal tibiae bone density and volume ( 6 weeks post-pellet) } \\
\hline $\begin{array}{l}\mathrm{aBMD} \\
\left(\mathrm{mg} / \mathrm{cm}^{2}\right)\end{array}$ & $\begin{array}{l}89.3 \\
(2.2)\end{array}$ & $\begin{array}{l}151.1 \\
(2.9)\end{array}$ & $\begin{array}{l}143.9 \\
(6.4)\end{array}$ & $<0.0001$ & $<0.0001$ & n.s. & $\begin{array}{l}99.4 \\
(4.8)\end{array}$ & $\begin{array}{l}134.3 \\
(4.5)\end{array}$ & $<0.0001$ & n.s. & n.s. \\
\hline BV/TV (\%) & $\begin{array}{l}12.5 \\
(2.0)\end{array}$ & $\begin{array}{l}82.7 \\
(2.7)\end{array}$ & $\begin{array}{l}91.1 \\
(2.4)\end{array}$ & $<0.0001$ & $<0.0001$ & n.s. & $10.1(0.9)$ & $\begin{array}{l}59.5 \\
(3.4)\end{array}$ & $<0.0001$ & n.s. & $<0.0001$ \\
\hline \multicolumn{12}{|c|}{ Bone turnover markers ( 2 weeks post-pellet; relative to mature control) } \\
\hline P1NP & $1.8(0.2)$ & $\begin{array}{l}2.4 \\
(0.2)\end{array}$ & $\begin{array}{l}2.5 \\
(0.3)\end{array}$ & 0.0401 & 0.0197 & n.s. & $1.0(0.1)$ & $\begin{array}{l}0.8 \\
(0.1)\end{array}$ & n.s. & 0.0064 & $<0.0001$ \\
\hline CTX-1 & $1.43(0.1)$ & $\begin{array}{l}1.9 \\
(0.1)\end{array}$ & $\begin{array}{l}1.5 \\
(0.1)\end{array}$ & 0.0142 & n.s. & n.s. & $1.0(0.2)$ & $\begin{array}{l}1.5 \\
(0.2)\end{array}$ & 0.0066 & 0.0166 & n.s. \\
\hline \multicolumn{12}{|c|}{ Bone cells ( 2 weeks post-pellet) } \\
\hline $\begin{array}{l}\text { N.Ob/BS } \\
(\mathrm{mm})\end{array}$ & $\begin{array}{l}33.1 \\
(0.7)\end{array}$ & $\begin{array}{l}36.1 \\
(2.1)\end{array}$ & $\begin{array}{l}39.18 \\
(4.3)\end{array}$ & n.s. & n.s. & n.s. & $27.1(6.6)$ & $\begin{array}{l}31.4 \\
(4.2)\end{array}$ & n.s. & n.s. & n.s. \\
\hline $\mathrm{N} . \mathrm{Ob} / \mathrm{mm}^{2}$ & $\begin{array}{l}393.4 \\
(63.0)\end{array}$ & $\begin{array}{l}765.8 \\
(86.3)\end{array}$ & $\begin{array}{l}849.2 \\
(116.1)\end{array}$ & 0.0051 & 0.0011 & n.s. & $\begin{array}{l}240.0 \\
(70.61)\end{array}$ & $\begin{array}{l}528.3 \\
(5.8)\end{array}$ & n.s. & n.s. & 0.0278 \\
\hline $\begin{array}{l}\text { N.Oc/BS } \\
(\mathrm{mm})\end{array}$ & $8.8(1.1)$ & $\begin{array}{l}9.5 \\
(0.6)\end{array}$ & $\begin{array}{l}9.3 \\
(0.4)\end{array}$ & n.s. & n.s. & n.s. & $7.6(2.4)$ & $\begin{array}{l}8.3 \\
(1.5)\end{array}$ & n.s. & n.s. & n.s. \\
\hline N.Oc $/ \mathrm{mm}^{2}$ & $\begin{array}{l}112.9 \\
(22.7)\end{array}$ & $\begin{array}{l}202.0 \\
(22.9)\end{array}$ & $\begin{array}{l}217.4 \\
(14.6)\end{array}$ & 0.0237 & 0.0097 & n.s. & $\begin{array}{l}64.7 \\
(22.0)\end{array}$ & $\begin{array}{l}170.1 \\
(47.2)\end{array}$ & 0.0263 & n.s. & n.s. \\
\hline
\end{tabular}

${ }^{a}$ P-values determined by1-way ANOVA with Fisher's LSD test. N.Ob/BS (mm): Osteoblast number per bone surface; N.Ob/mm²: number of osteoblasts lining trabecular bone per tissue area; N.Oc/BS $(\mathrm{mm})$ : osteoclast number per bone surface; N.Oc/mm²: number of osteoclasts lining trabecular bone per tissue area; aBMD: areal bone mineral density; BV/TV: bone volume/total volume; n.s.: not significant.

Age-related differences in bone resorption in $\mathrm{E}_{2}$-treated mice were less evident in these ovary-intact mice. While osteoclast number (N.Oc) per bone surface was not changed by $\mathrm{E}_{2}$ treatment in mice of either age, N.Oc per bone area increased significantly and similarly in age of both ages, such that there was no difference in Oc counts in young vs. mature $\mathrm{E}_{2}$ treated mice [Table 1]. Similarly, CTX-1 levels in $0.72 \mathrm{mg} \mathrm{E}_{2}-$ treated mice of both ages were the same [Table 1]. In toto, these data demonstrate that the greater net increases in bone in young ( $v s$. mature) mice treated with same $\mathrm{E}_{2}$ dose were attributable to higher rates of bone formation, which were positively associated with osteolytic lesion size, but not incidence, in tumorinoculated young ( $v s$. mature) mice supplemented with the same $\mathrm{E}_{2}(0.72 \mathrm{mg})$ dose.

\section{Assessing dose-dependency of $\mathrm{E}_{2}$ effects on bone turnover in tumor-naive vs. progression of osteolytic ER+ BMET lesions in ER+ tumor cell-inoculated 5-week-old mice}

Because significant $\mathrm{E}_{2}$ effects on bone occurred in mice of both ages, bone effects of a range of lower $\mathrm{E}_{2}$ doses previously reported to support dose-dependent growth of orthotopic MCF-7 tumors in vivo ${ }^{[17]}$ were next assessed in mice of a single age to determine whether an $\mathrm{E}_{2}$ dose could be identified that did not significantly alter bone. Remarkably, $\mathrm{E}_{2}$-induced increases in total tibial aBMD were identical for all doses, plateauing 3 weeks after $\mathrm{E}_{2}$-pellet placement in 5-week-old mice [Figure 3A]. Other bone parameters including proximal tibial aBMD or BV/TV, bone turnover markers, and N.Ob or N.Oc were also similarly increased in response to the lowest $\mathrm{E}_{2}$ dose $(0.05 \mathrm{mg}) v \mathrm{~s}$. the highest $\mathrm{E}_{2}$ dose $(0.72 \mathrm{mg})$ tested, without any dose-dependence [Table 1]. Having documented essentially identical bone microenvironment effects over this entire range of $\mathrm{E}_{2}$ doses known to support in vivo MCF-7 proliferation at orthotopic sites, with evidence of dose-dependent increases in circulating $\mathrm{E}_{2}$ levels across the range of doses [Supplementary Figure 1], the effects of this $\mathrm{E}_{2}$ dosing regimen on ER+ BMET progression in MCF-7 cell-inoculated mice of the same age 

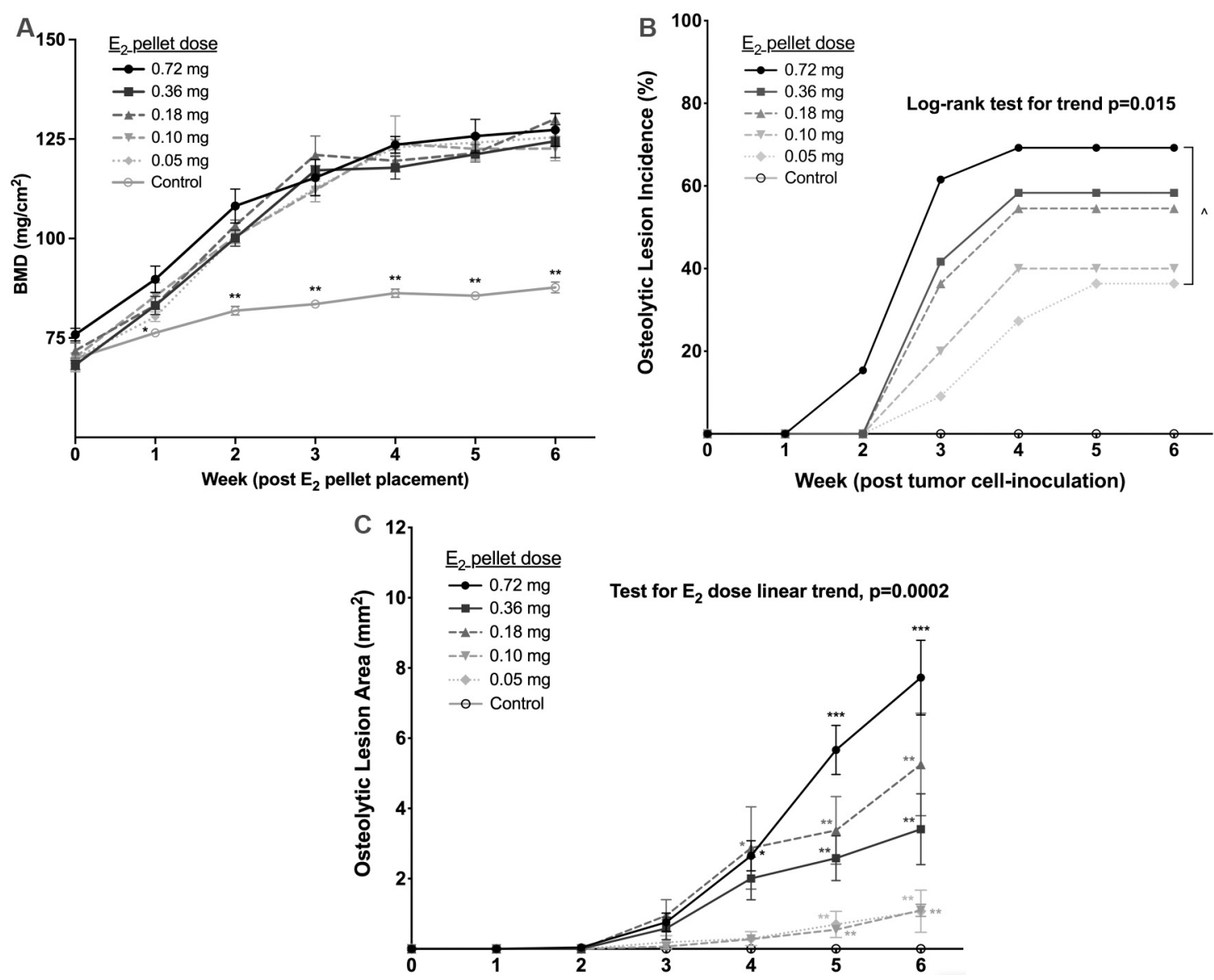

Figure 3. Comparison of dose effects of $E_{2}$ on bone mineral density in tumor-naive vs. osteolytic ER+ BMET progression in tumorinoculated mice. (A) Areal bone mineral density (BMD) of tibiae in tumor-naive 4-week-old mice treated with the indicated doses of $E_{2}$ (vs. age-matched controls), as measured by DXA ( $n=6-8 /$ group). ${ }^{*} P \leq 0.010 .72 \mathrm{mg} E_{2} v s$. control; ${ }^{*} P \leq 0.01$ for each $E_{2}$ dose vs. control, with no statistical differences between $E_{2}$ doses, by mixed-effects analysis with Tukey post-test. (B) Osteolytic lesion incidence and (C) osteolytic lesion area in age-matched mice inoculated at 5 weeks of age with ER+ tumor cells ( $n=10-13 /$ group) 3 days postsupplementation with the same $E_{2}$ doses ( $v s$. no $E_{2}$ controls; open circles). P-values for $E_{2}$ dosing trends were calculated using Kaplan Meier analysis with log-rank test for incidence, or 1-way ANOVA of AUC data with post-test for linear trend for lesion area. ${ }^{\wedge} P \leq 0.05$ $0.72 \mathrm{mg} \mathrm{E}_{2}$ vs. $0.05 \mathrm{mg} \mathrm{E}_{2}$ by log-rank (Mantel-Cox) test. ${ }^{\star} P \leq 0.05$ vs. controls or $0.05 \mathrm{mg} \mathrm{E}_{2 i}{ }^{\star \star} P \leq 0.05$ vs. control, $0.05,0.10$, or 0.72 $\mathrm{mg} \mathrm{E}_{2} ;{ }^{* \star \star} P \leq 0.05$ vs. every dose, by 2-way ANOVA with Holm-Sidak post-test.

were assessed. In mice treated with increasing doses of $\mathrm{E}_{2}$, osteolytic ER+ BMET lesions formed in a dosedependent fashion with respect to both incidence and size (Figure 3B-C, $P \leq 0.05$ ), with the highest dose of $\mathrm{E}_{2}$ tested $(0.72 \mathrm{mg})$ forming osteolytic lesions with a similar size and incidence 6 weeks post-tumor inoculation as occurs in a commonly used non- $\mathrm{E}_{2}$-supplemented ER- MDA-MB-231 BMET model at week $3^{[41]}$. The 7-fold larger size and higher incidence of osteolytic lesions in MCF-7-inoculated mice treated with the highest $(0.72 \mathrm{mg}) v s$. lowest $(0.05 \mathrm{mg}) \mathrm{E}_{2}$ dose contrasts with dose-dependent effects of $\mathrm{E}_{2}$ in mice inoculated instead with ER- MDA-MB-231 cells; ER- osteolytic lesion size, while increased by $\mathrm{E}_{2}$ treatment, as described above, was not statistically different in mice treated with the highest $(0.72 \mathrm{mg}) v s$. lowest $(0.05$ $\mathrm{mg}) \mathrm{E}_{2}$ doses $(P=0.11, n=9-12)$ and osteolytic lesion incidence was unchanged by any $\mathrm{E}_{2}$ dose ( $v s$. nonsupplemented controls, data not shown). Thus, while bone anabolism and osteolytic ER- BMET lesion progression were each induced by $\mathrm{E}_{2}$ in 5 -week-old mice, neither exhibited $\mathrm{E}_{2}$-dose dependence; in contrast, the size and incidence of osteolytic ER+ BMET lesion progression were $\mathrm{E}_{2}$ inducible and $\mathrm{E}_{2}$-dose dependent. 


\section{Assessing possible $E_{2}$ dose-dependency of ER+ tumor cell dissemination to bone}

Because $\mathrm{E}_{2}$ pellets were placed 3 days prior to tumor cell inoculation to allow for stabilization, studies were undertaken to assess possible dose-dependent $\mathrm{E}_{2}$ effects on $\mathrm{ER}+$ tumor cell dissemination to bone. Following inoculation of DiD-labelled MCF-7 cells, DiD+tumor cells detected in the proximal tibia - while trending slightly higher in $\mathrm{E}_{2}$-treated $v s$. control mice $24 \mathrm{~h}$ post-inoculation [Supplementary Figure 2] - were not statistically different. Most importantly, there was no evidence of a dose-dependent $\mathrm{E}_{2}$ effect in mice treated with the lowest $(0.05 \mathrm{mg}) v s$. highest $(0.72 \mathrm{mg}) \mathrm{E}_{2}$ doses tested [Supplementary Figure 2]. There was also no evidence of an age effect, when comparing bone disseminated DiD+ MCF-7 cells in young vs. skeletally mature mice treated with $0.72 \mathrm{mg} \mathrm{E}_{2}$ [Supplementary Figure 2].

\section{Assessing possible $E_{2}$ dose-dependency of ER+ tumor burden and proliferation in bone}

Because proliferative effects of $\mathrm{E}_{2}$ on ER+ MCF-7 cells are well described in vitro and in vivo at orthotopic sites $^{[17,58]}$, a possible $\mathrm{E}_{2}$ dose-dependency for histologic tumor burden (size) and tumor cell proliferation in bone were assessed 6 weeks post-inoculation, when osteolytic lesion size was still increasing. While the mean area for cytokeratin+ ER+ breast cancer tumors in bone tended to be smaller for lower $\mathrm{E}_{2}$ doses, the range of tumor sizes was similar across doses without a statistical difference in mean values [Figure $4 \mathrm{~A}$ ]; nor was there a significant linear trend for increasing doses. Tumor burden in $0.72 \mathrm{mg} \mathrm{E}_{2}$-pelleted young vs. skeletally mature mice was also not statistically different [Figure 4A]. Tumor cell proliferation, assessed by Ki67-positivity, was notable in $\mathrm{E}_{2}$-supplemented mice (> 60\%), but again was without $\mathrm{E}_{2}$-dose or agedependency [Figure 4B].

\section{Assessing $E_{2}$ dose-dependency of ER+ tumor-associated osteolysis}

Having eliminated differential tumor cell dissemination or proliferative effects of $\mathrm{E}_{2}$ as being responsible for the $\mathrm{E}_{2}$ dose-dependence of ER+ osteolytic BMET lesion progression, dose-dependent effects of $\mathrm{E}_{2}$ on tumorassociated osteolysis-specific mechanisms were next assessed. While $\mathrm{E}_{2}$ suppresses osteoclast numbers in estrogen-deficient bone ${ }^{[60]}$, in ovary-intact tumor-naive mice, neither the highest $(0.72 \mathrm{mg})$ nor the lowest (0.05 mg) $\mathrm{E}_{2}$ dose altered osteoclast numbers per bone surface at 2 weeks [Table 1] or 6 weeks (data not shown). However, consistent with $\mathrm{E}_{2}$ dose-dependent increases in ER+ BMETs osteolytic lesion size and incidence [Figure $3 \mathrm{~B}-\mathrm{C}$ ], the number of bone-resorbing osteoclasts at the tumor-bone interface of ER+ tumor cell-inoculated mice treated with the highest $(0.72 \mathrm{mg}) \mathrm{E}_{2}$ dose was significantly greater than that in mice treated with the lowest $(0.05 \mathrm{mg}) \mathrm{E}_{2}$ dose, where osteoclast numbers on bone surfaces interfacing with tumors [Figure 5A] were not different from those in age-matched, tumor-naive control mice [N.Oc/BS, 10.9 $\pm 1.8(n=6), P>0.05]$. The osteolytic factor, parathyroid hormone-related protein (PTHrP), which is expressed in most clinical breast cancer BMET ${ }^{[8,11,59,61-63]}$, was secreted constitutively from ER+ MCF-7 tumor cells used for inoculation, while constitutive PTHrP secretion from ER+ tumor cells isolated from MCF-7 BMET lesions was 2- to 3 -fold higher $(P \leq 0.05)$ [Figure $5 B$ ]. In both inoculated and BMET-derived cells, tumoral PTHrP secretion was further increased $(P \leq 0.05)$ in response to $\mathrm{E}_{2}$ treatment, resulting in 2 -fold higher levels of $\mathrm{E}_{2}$-induced PTHrP secretion from BMET-derived ( $v s$. inoculated) ER+ tumor cells. As with in vivo $\mathrm{BMET}$-associated osteolysis, $\mathrm{E}_{2}$-inducible $\mathrm{PTHrP}$ secretion in vitro was also dose-dependent [Figure 5C]. Moreover, $\mathrm{E}_{2}$ induction of PTHrP secretion was ER $\alpha$-mediated; MPP, an ER $\alpha$-specific antagonist $^{[64]}$ that did not alter tumoral PTHrP secretion (data not shown), blocked $\mathrm{E}_{2}$-induced PTHrP in BMET-derived tumor cells (Figure 5D; $P \leq 0.01$ ). Furthermore, PPT, an ER $\alpha$ specific agonist with an affinity for $\mathrm{ER} \alpha$ similar to that of $\mathrm{E}_{2}$ (and 410-fold higher for $\mathrm{ER} \alpha v s$. ER $\left.\beta\right)^{[65]}$, significantly induced PTHrP to identical levels as compared to an equimolar concentration of $\mathrm{E}_{2}$ [Figure $5 \mathrm{D}$ ].

\section{DISCUSSION}

Anti-estrogen hormone therapies and bisphosphonates each have a proven benefit in reducing the development and progression of osteolytic ER+ BMETs; however, BMETs still occur in $~ 80 \%$ of women 

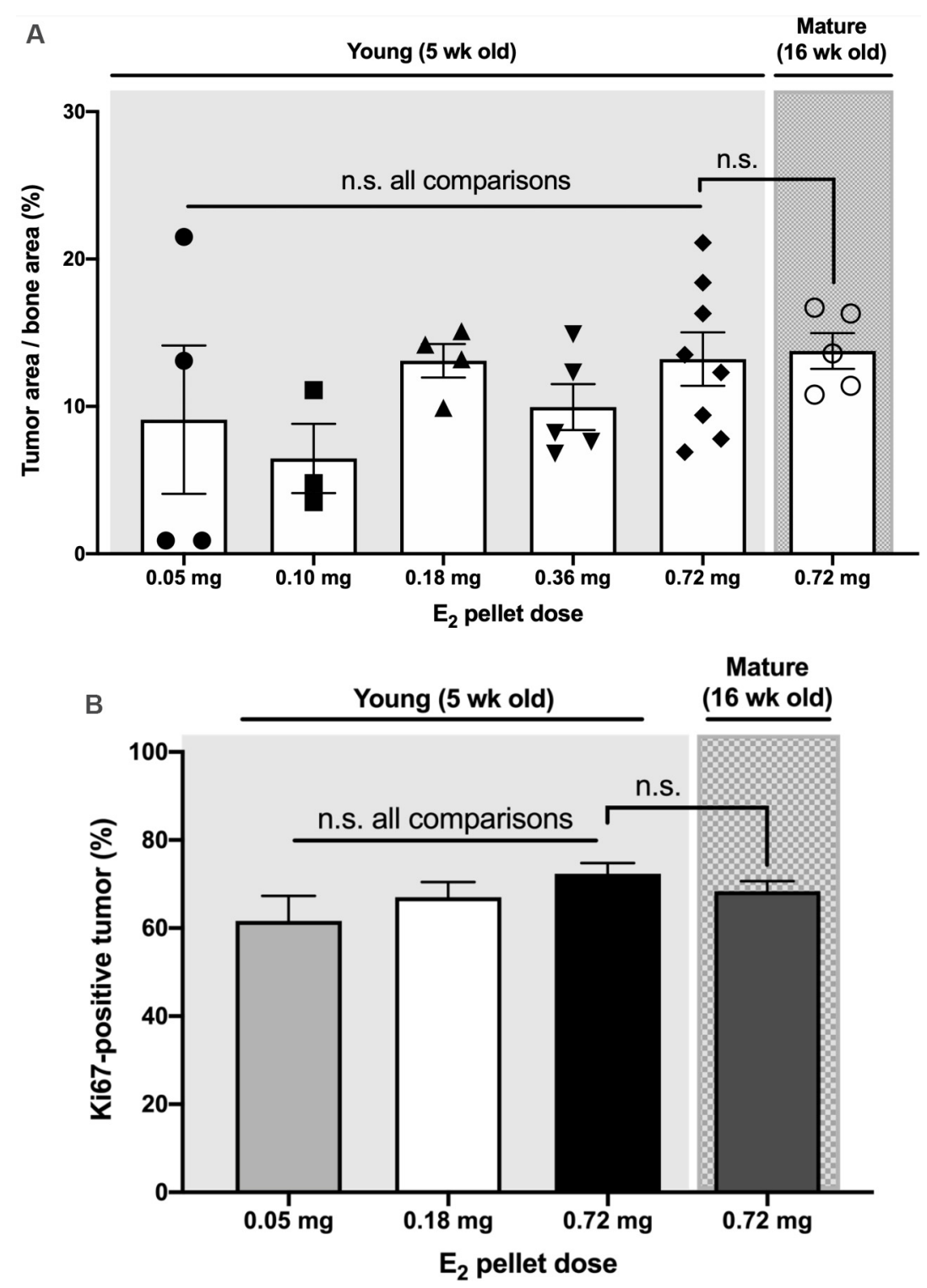

Figure 4. $E_{2}$ effects on histologic tumor burden and tumor cell proliferation in bone. (A) Cytokeratin-positive breast cancer tumor area in hind limbs, normalized to bone area in mid-sagittal sections, 6 weeks post-ER+ tumor cell inoculation of 5- or 16-week old mice. There was no linear trend in tumor burden with increasing $E_{2}$ doses, and no significant differences (n.s.) between $E_{2}$ doses, or between young and mature mice treated with $0.72 \mathrm{mg} \mathrm{E}_{2}$ as tested by 1-way ANOVA with Sidak post-test ( $n=3-9 /$ group). (B) Proliferating, Ki67-positive cells in hind limb breast cancer tumors (\% of total) 6 weeks post tumor-inoculation. There were no significant differences (n.s) in the proportion of Ki67-positive tumor cells between $E_{2}$ doses [including the lowest $(0.05 \mathrm{mg})$ and highest $(0.72 \mathrm{mg})$ ], or between young (5-week) and mature (16-week) mice treated with $0.72 \mathrm{mg} \mathrm{E}_{2}$, as calculated by 1-way ANOVA with Sidak post-test ( $n=$ 8-18/group).

with ER+ metastatic breast cancer and remain incurable ${ }^{[4,66-71]}$. The recent addition of agents acting downstream of ER $\alpha$ to decrease proliferation (CDK4/6 inhibitors), while not curative, has yielded significant benefits ${ }^{[72]}$, likely due in part to the high prevalence of ligand-independent, activating ER $\alpha$ mutations in ER+ metastatic breast cancer ${ }^{[12]}$. Similarly, if separate osteolytic effects of tumoral ER $\alpha$ signaling are also demonstrated to drive ER+ BMET progression, novel molecular approaches targeting specific tumoral osteolytic pathways downstream of ER $\alpha$ could provide new avenues for skeletal therapeutics to block BMET progression for ER+ tumors, which comprise the majority of breast cancer BMET. 

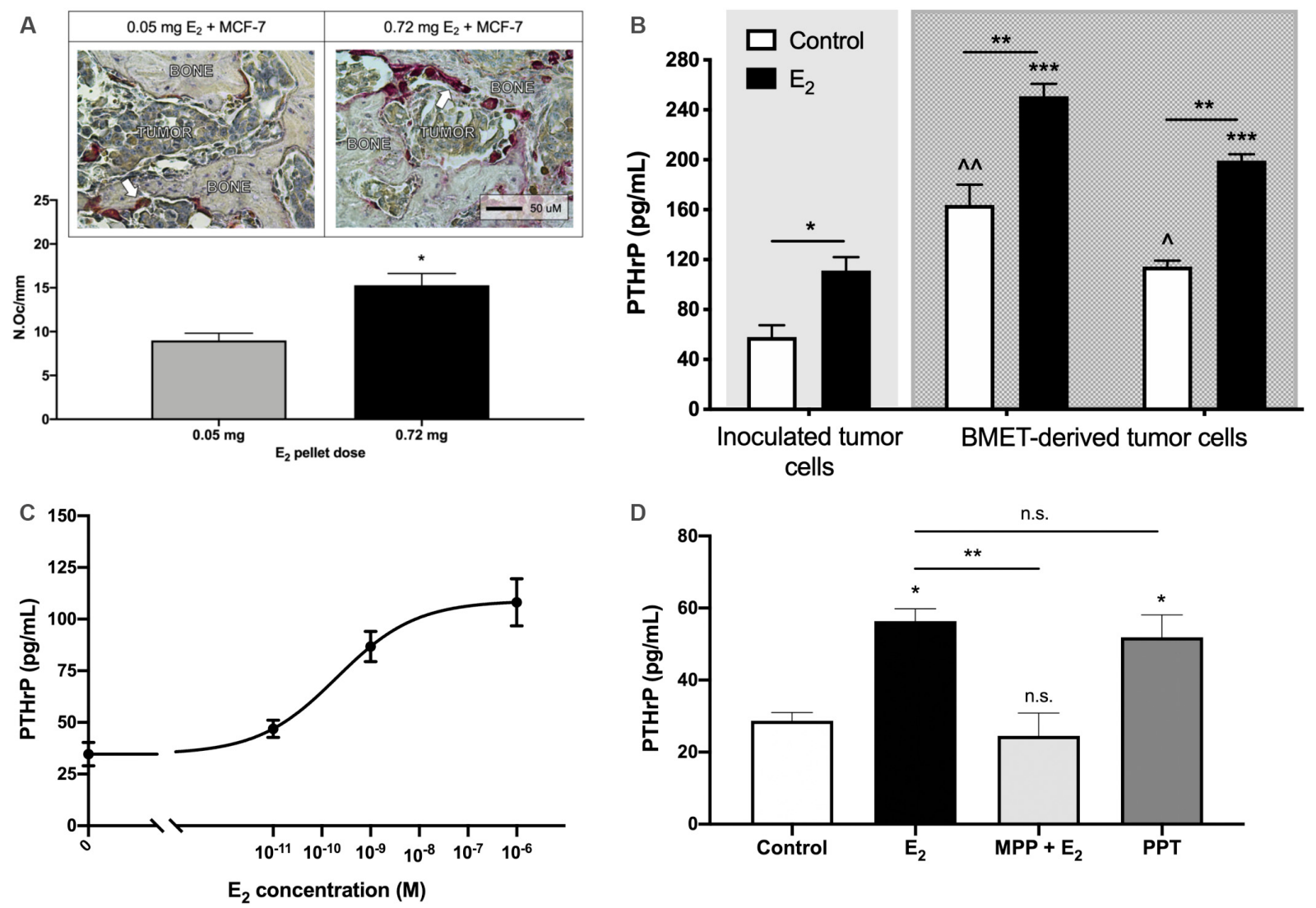

Figure 5. $\mathrm{E}_{2}$ effects on tumoral osteolysis and secretion of osteolytic PTHrP. (A) Osteoclast number at tumor-bone interface (N.Oc/mm) in tibiae from tumor cell-inoculated mice supplemented with the lowest $(0.05 \mathrm{mg})$ and highest $(0.72 \mathrm{mg}) \mathrm{E}_{2}$ doses $(n=8-11$ tibiae/group), with representative images of TRAP-positive multinucleated osteoclasts (see arrow for example of red-stained multinucleated osteoclast). ${ }^{*} P<0.01$ by $t$-test. (B) Osteolytic PTHrP secretion from inoculated tumor cells vs. ER+ tumor cells isolated from BMETs of 2 different mice. Cells were treated with $10^{-7} \mathrm{M} \mathrm{E}_{2}$ or media control for $48 \mathrm{~h}$ after 4 days in $\mathrm{E}_{2}$-free media $(n=4 / \mathrm{group})$. Cell number, as assessed by MTT assay, was not different between cell lines or altered by $E_{2}$ treatment (data not shown). ${ }^{\star} P \leq 0.05$, ${ }^{\star \star} P$ $\leq 0.001 \mathrm{E}_{2}$ vs. control; ${ }^{\wedge} P \leq 0.05,{ }^{\wedge} P \leq 0.0001$ inoculated vs. BMET-derived control cells; ${ }^{\star \star \star}{ }^{\star \star} P \leq 0.001$ inoculated vs. BMET-derived $E_{2}-$ treated cells, by 2-way ANOVA with Tukey post-test. (C) $E_{2}$ dose-dependency of PTHrP secretion in MCF-7 maintained in $E_{2}$-deplete media for 4 days prior to treatment with various concentrations of $E_{2}(M)$, as indicated, for $72 \mathrm{~h}(n=3-4 /$ group). (D) PTHrP secretion from ER+ BMET-derived cells treated with $E_{2}\left(10^{-8} M\right), E_{2}$ and $M P P\left(10^{-6} M, E R \alpha\right.$ antagonist), PPT $\left(10^{-8} M, E R \alpha\right.$ agonist), or media control for $52 \mathrm{~h}$ after 4 days in $\mathrm{E}_{2}$-deplete media ( $n=3-4$ /group). Cell numbers (by MTT assay) were not altered by treatments (data not shown). ${ }^{\star} P \leq 0.05$ vs. control; ${ }^{*} P \leq 0.01 \mathrm{E}_{2} v$ s. MPP $+\mathrm{E}_{2}$; not significant (n.s.) vs. control or as shown, by 1-way ANOVA with Sidak posttest. MPP: Methyl-piperidino-pyrazole; PPT: propyl pyrazole triol; PTHrP: parathyroid hormone-related protein.

BMETs are uniquely increased (2-fold) in metastatic ER+ breast cancers as compared to metastases at other sites, where metastatic prevalence is either the same or reduced as compared to ER- tumors, and osteolysis is a bone- and tumor-specific event (e.g., primarily osteolytic in breast cancer $v s$. osteosclerotic in prostate cancer) known to be dependent on tumor-derived factors, such as $\mathrm{PTHr}^{[8-11]}$. Thus, we posited that the apparent proclivity of bone-disseminated ER+ ( $v s$. ER-) breast cancer cells to form clinically-evident osteolytic BMET could be attributable, at least in part, to pro-osteolytic effects of tumoral ER $\alpha$ signaling. The studies described here, which to our knowledge are the first to examine the $\mathrm{E}_{2}$ dose dependence of in vivo osteolytic ER+ BMET progression, support this postulate; over the range of $\mathrm{E}_{2}$ doses tested, while $\mathrm{E}_{2}$ effects on bone turnover or tumor cell seeding and proliferation in bone were constant, tumor-associated osteolysis and osteoclast formation at the bone/tumor interface in ER+ tumor-bearing mice increased in an $\mathrm{E}_{2}$ dose-dependent fashion, contrasting with well-described inhibitory effects of $\mathrm{E}_{2}$ on osteoclast formation in normal bone ${ }^{[32,60]}$. The additional finding of enhanced, $\mathrm{E}_{2}$ dose-dependent, $\mathrm{ER} \alpha$-regulated secretion of 
PTHrP, an osteolytic factor expressed in most clinical BMETs ${ }^{[2,663]}$, from BMET-derived ER+ breast cancer cells further supports this postulate and provides possible mechanistic insights for specific pathways downstream of tumoral ER $\alpha$ activation that may contribute to ER+ BMET-associated osteolysis. The enhanced secretion of PTHrP regulated by ER $\alpha$ from BMET-derived tumor cells, in particular, suggests: (1) $\mathrm{ER} \alpha$ expression in ER+ cells metastatic to bone - rather than being just a biomarker for BMETs - may also be a potential molecular driver of osteolysis and metastatic progression in bone; and/or (2) either a subpopulation of highly PTHrP-expressing cells preferentially formed BMETs and/or the bone microenvironment altered the phenotype of bone-disseminated tumor cells to favor PTHrP-mediated osteolysis. Either of these possibilities is consistent with clinical observations that PTHrP-positivity in breast cancer is greater in BMET than in other metastatic sites or in primary tumors ${ }^{[2]}$, a finding also verified in pre-clinical murine studies documenting greater PTHrP expression in human breast cancer cells spontaneously forming metastases in bone $v s$. other $\operatorname{sites}^{[73]}$. The possible mechanistic importance of tumoral PTHrP secretion in promoting tumor-associated osteolysis and, in turn, osteolytic BMET progression, has already been established in one commonly studied pre-clinical ER- human BMET model, where osteolytic BMET progression does not occur in the absence of tumoral PTHrP bioactivity ${ }^{[8,42]}$. Also of particular relevance to the current studies, while $\mathrm{E}_{2}$-regulation of PTHrP expression in ER+ MCF7 cells has not, to our knowledge, been examined by laboratories other than our own ${ }^{[74]}$, overexpression of PTHrP by stable transfection in MCF-7 cells has been demonstrated to increase osteolysis specifically, in concert with a significant increase in osteolytic BMET progression (as compared to wild-type cells) ${ }^{[26]}$. Thus, existing evidence supports the postulate that enhanced secretion of PTHrP mediated by ER $\alpha$ in ER+ tumor cells disseminated to bone, as documented here, may be one specific pathway driving $\mathrm{E}_{2}$ dose-dependent tumor osteolysis and osteolytic ER+ BMET progression documented in vivo.

Clearly, though, these studies have limitations. Indeed, while a bone-specific hypothesis for tumoral ER $\alpha$ signaling driving BMET progression via mediation of tumor-associated osteolysis is straightforward, testing in pre-clinical models, where $\mathrm{E}_{2}$ supplementation is necessary to support robust progression of osteolytic BMET and a syngeneic mouse model is not available, is difficult since $\mathrm{E}_{2}$ has anabolic effects on the bone microenvironment and also clearly drives ER+ breast cancer cell proliferation, which is not unique to the bone microenvironment. Thus, while prior experiments utilizing $\mathrm{E}_{2}$-driven ER+ human breast cancer xenograft models and a single dose of $\mathrm{E}_{2}$ have demonstrated tamoxifen-inhibition of ER+ BMET following intracardiac tumor cell inoculation, or a role of zoledronic acid or tumor cell PREX1 expression in regulating dissemination of ER+ cells from primary orthotopic tumors ultimately home to bone ${ }^{[18,21,2]]}$, none have been able to elucidate the relative importance of bone $v s$. tumor effects of $\mathrm{E}_{2}$, or other agents with dual bone $v s$. tumor effects, such as zoledronic acid. In the experiments described here, which are the first, to our knowledge, to test $\mathrm{E}_{2}$ dose dependency in an ER+ BMET model, the constancy across doses of $\mathrm{E}_{2}$-driven bone anabolism - an anticipated effect given $\mathrm{E}_{2}$ 's known direct and/or indirect (via $\mathrm{T}$ and B lymphocytes, with only the latter being present in the model used here) stimulatory effects on osteoblasts and inhibition of myeloid-derived osteoclasts ${ }^{[32,60]}$ - could not account for the $\mathrm{E}_{2}$ dose-dependency of tumor-associated osteolysis. The osteolytic capacity of the ER+ tumors to overcome the marked increase in bone occurring in $\mathrm{E}_{2}$-treated mice, yielding osteolytic lesions similar in size and incidence to those reported in ER- models where anabolic increases in bone do not occur ${ }^{[41]}$, was also notable. However, the possibility that bone anabolism may have played a permissive, albeit constant, role in BMET progression in this ER+ model cannot be ruled out.

While the $\mathrm{E}_{2}$ dose-dependency of ER+ osteolytic BMET progression was not attributable to anabolic $\mathrm{E}_{2}$ bone effects given the constancy of this tumor microenvironment effect across doses, $\mathrm{E}_{2}$-driven bone anabolism clearly had independent pro-metastatic effects as well. Larger osteolytic lesion sizes in young (vs. mature) 
mice treated with the same $\mathrm{E}_{2}$ dose appeared attributable to greater $\mathrm{E}_{2}$-mediated anabolism in young mice since tumor cell dissemination and proliferation were otherwise the same. Increased osteolytic BMET lesion size in $\mathrm{E}_{2}$-treated ( $v s$. control) mice inoculated with ER- breast cancer cells further confirmed a role of anabolic bone microenvironmental effects of $\mathrm{E}_{2}$ in driving osteolytic breast cancer BMET progression, independent of tumoral ER signaling, consistent with previous similar reports in ER- BMET models ${ }^{[35,36]}$. Because these experiments provide the first evidence, to our knowledge, that bone anabolic effects of $\mathrm{E}_{2}$ promote ER+ BMET progression subsequent to tumor cell dissemination to bone (as bone seeding was $\mathrm{E}_{2}-$ and age-independent), this finding may have clinical implications when estrogens and/or other anabolic agents are used to treat osteoporosis in post-menopausal women ${ }^{[75]}$, an age where breast cancer incidence is the highest ${ }^{[76]}$ and silent bone micrometastases may already be present prior to a ER+ breast cancer diagnosis ${ }^{[77-80]}$. However, additional studies are required to explore this more specifically for both ER+ and ER- BMET, as, for example, studies evaluating anabolic effects of parathyroid hormone (PTH) on ERBMET progression have yielded mixed results to date ${ }^{[28,81,82]}$. Additionally, it should be noted that the absence of an $\mathrm{E}_{2}$ effect on ER+ tumor cell dissemination to bone confirms previous reports ${ }^{[20,27]}$ and is consistent with the clinical observation of similar incidences of bone micrometastases in clinical series of patients with ER+ or ER- breast cancers ${ }^{[77-80]}$.

Lastly, the study of only a single ER+ breast cancer cell line in these pre-clinical experiments is a limitation. However, it should be noted that studies using breast cancer cells derived from a single ER- cell line (MDAMB-231), which shares fewer attributes with clinical breast tumors than the MCF-7 cells used here ${ }^{[83]}$, account for a large portion of pre-clinical breast cancer BMET research, but have still yielded important clinical insights, including the now standard therapeutic use of bisphosphonates for BMET ${ }^{[84]}$. Because of the reported low take-rates and rare formation of BMETs by ER+ patient derived xenografts $(\mathrm{PDX})^{[85-88]}$, ER+ MCF-7 cells were initially chosen for these studies given their well-described ability to form osteolytic BMETs in $\mathrm{E}_{2}$-supplemented mice ${ }^{[20-26]}$. In addition, inoculation of other commonly used ER+ cell lines known to disseminate to bone (T47D and ZR-75-1) ${ }^{[18,89]}$ did not result in osteolytic BMET formation, with or without $\mathrm{E}_{2}$ supplementation (data not shown). However, this difference in osteolytic BMET potential between ER+tumor cells provides evidence that the pro-osteolytic effects of $\mathrm{E}_{2}$ signaling in bonedisseminated ER+ breast cancer cells are likely also interdependent on other cellular transformations and signaling pathways present in ER+ tumor cells within the bone microenvironment - a postulate that awaits further testing.

In conclusion, while the study of ER+ breast cancer BMETs is complicated by the duality of ER $\alpha$ signaling effects in bone $v s$. bone-disseminated ER+ tumor cells, the experiments reported here, by taking advantage of differential dose-dependent effects of $\mathrm{E}_{2}$ on bone $v s$. ER+ tumor-associated osteolysis, suggest that ER+ osteolytic BMET progression may be specifically promoted by tumoral ER $\alpha$ signaling via the induction of osteolysis. Thus, additional bone-specific molecular targets downstream of ER $\alpha$, in addition to those that drive proliferation, may complement existing therapeutics for the treatment of osteolytic ER+ BMETs, particularly for HT-resistant metastatic ER+ breast cancer, while potentially providing a mechanistic basis for the long-standing clinical observation of the association of tumoral ER $\alpha$ expression with breast cancer metastatic risk specific to bone.

\section{DECLARATIONS}

\section{Acknowledgements}

We would like to acknowledge Andrea Grantham in memoriam for her many years of artful histological processing of our murine bone samples at the University of Arizona and for reminding us that a life outside the lab lived in the service of others is the most rewarding. We would also like to thank Alfred Li at the San 
Francisco VA Medical Center Endocrine Research Unit for generating the microCT images and data, and acknowledge University of Arizona undergraduates, Madison Egan, Lily Alvord, Albiya Thomas, and Geethika Ameneni, for their contributions to the data analyses.

\section{Authors' contributions}

Designed the research: Cheng JN, Funk JL

Acquired the data: Cheng JN, Frye JB, Whitman SA

Analyzed data and performed statistical analyses: Cheng JN, Frye JB, Whitman SA, Kunihiro AG, Brickey JA, Funk JL

First draft of the manuscript: Cheng JN, Funk JL

\section{Availability of data and materials}

Not applicable.

\section{Financial support and sponsorship}

This work was supported by the National Cancer Institute (NCI) of the National Institutes of Health (NIH) (R03CA181893 and R01CA174926 to JLF, T32CA00923, P30CA023074); METAvivor (Translational Research Award, JLF); the Phoenix Chapter of ARCS Foundation (JNC); and the Louise Foucar Marshall Foundation Dissertation Fellowship (JNC).

\section{Conflicts of interest}

All authors declared that there are no conflicts of interest.

\section{Ethical approval and consent to participate}

Not applicable.

\section{Consent for publication}

Not applicable.

\section{Copyright}

(c) The Author(s) 2021.

\section{REFERENCES}

1. Bray F, Ferlay J, Soerjomataram I, Siegel RL, Torre LA, Jemal A. Global cancer statistics 2018: GLOBOCAN estimates of incidence and mortality worldwide for 36 cancers in 185 countries. CA Cancer J Clin 2018;68:394-424. DOI PubMed

2. Macedo F, Ladeira K, Pinho F, et al. Bone metastases: an overview. Oncol Rev 2017;11:321. DOI PubMed PMC

3. Kozlow W, Guise TA. Breast cancer metastasis to bone: mechanisms of osteolysis and implications for therapy. J Mammary Gland Biol Neoplasia 2005;10:169-80. DOI PubMed

4. Soni A, Ren Z, Hameed O, et al. Breast cancer subtypes predispose the site of distant metastases. Am J Clin Pathol 2015;143:471-8. DOI PubMed

5. Hilton JF, Amir E, Hopkins S, et al. Acquisition of metastatic tissue from patients with bone metastases from breast cancer. Breast Cancer Res Treat 2011;129:761-5. DOI PubMed

6. Kamby C, Rasmussen BB, Kristensen B. Oestrogen receptor status of primary breast carcinomas and their metastases. Relation to pattern of spread and survival after recurrence. Br J Cancer 1989;60:252-7. DOI PubMed PMC

7. Aurilio G, Monfardini L, Rizzo S, et al. Discordant hormone receptor and human epidermal growth factor receptor 2 status in bone metastases compared to primary breast cancer. Acta Oncol 2013;52:1649-56. DOI PubMed

8. Guise TA. Molecular mechanisms of osteolytic bone metastases. Cancer 2000;88:2892-8. DOI PubMed

9. Coleman RE, Croucher PI, Padhani AR, et al. Bone metastases. Nat Rev Dis Primers 2020;6:83. DOI PubMed

10. Guise TA. The vicious cycle of bone metastases. J Musculoskelet Neuronal Interact 2002;2:570-2. PubMed

11. Guise TA. Parathyroid hormone-related protein and bone metastases. Cancer 1997;80:1572-80. DOI PubMed

12. Reinert T, Barrios CH. Optimal management of hormone receptor positive metastatic breast cancer in 2016 . Ther Adv Med Oncol 2015;7:304-20. DOI PubMed PMC

13. Breast Cancer Trialists' Collaborative Group (EBCTCG). Effects of chemotherapy and hormonal therapy for early breast cancer on 
recurrence and 15-year survival: an overview of the randomised trials. Lancet 2005;365:1687-717. DOI PubMed

14. Zhao H, Zhou L, Shangguan AJ, Bulun SE. Aromatase expression and regulation in breast and endometrial cancer. J Mol Endocrinol 2016;57:R19-33. DOI PubMed PMC

15. Sjögren K, Lagerquist M, Moverare-Skrtic S, et al. Elevated aromatase expression in osteoblasts leads to increased bone mass without systemic adverse effects. J Bone Miner Res 2009;24:1263-70. DOI PubMed

16. Nilsson ME, Vandenput L, Tivesten A, et al. Measurement of a comprehensive sex steroid profile in rodent serum by high-sensitive gas chromatography-tandem mass spectrometry. Endocrinology 2015;156:2492-502. DOI PubMed

17. Osborne CK, Hobbs K, Clark GM. Effect of estrogens and antiestrogens on growth of human breast cancer cells in athymic nude mice. Cancer Res 1985;45:584-90. PubMed

18. Holen I, Walker M, Nutter F, et al. Oestrogen receptor positive breast cancer metastasis to bone: inhibition by targeting the bone microenvironment in vivo. Clin Exp Metastasis 2016;33:211-24. DOI PubMed

19. Ogba N, Manning NG, Bliesner BS, et al. Luminal breast cancer metastases and tumor arousal from dormancy are promoted by direct actions of estradiol and progesterone on the malignant cells. Breast Cancer Res 2014;16:48. DOI PubMed PMC

20. Sowder ME, Johnson RW. Enrichment and detection of bone disseminated tumor cells in models of low tumor burden. Sci Rep 2018;8:14299. DOI PubMed PMC

21. Canon J, Bryant R, Roudier M, Branstetter DG, Dougall WC. RANKL inhibition combined with tamoxifen treatment increases antitumor efficacy and prevents tumor-induced bone destruction in an estrogen receptor-positive breast cancer bone metastasis model. Breast Cancer Res Treat 2012;135:771-80. DOI PubMed

22. Fisher JL, Thomas-Mudge RJ, Elliott J, et al. Osteoprotegerin overexpression by breast cancer cells enhances orthotopic and osseous tumor growth and contrasts with that delivered therapeutically. Cancer Res 2006;66:3620-8. DOI PubMed

23. Gawrzak S, Rinaldi L, Gregorio S, et al. MSK1 regulates luminal cell differentiation and metastatic dormancy in $\mathrm{ER}^{+}$breast cancer. Nat Cell Biol 2018;20:211-21. DOI PubMed

24. Johnson RW, Finger EC, Olcina MM, et al. Induction of LIFR confers a dormancy phenotype in breast cancer cells disseminated to the bone marrow. Nat Cell Biol 2016;18:1078-89. DOI PubMed PMC

25. Pavlovic M, Arnal-Estapé A, Rojo F, et al. Enhanced MAF oncogene expression and breast cancer bone metastasis. J Natl Cancer Inst 2015;107:djv256. DOI PubMed PMC

26. Thomas RJ, Guise TA, Yin JJ, et al. Breast cancer cells interact with osteoblasts to support osteoclast formation. Endocrinology 1999;140:4451-8. DOI PubMed

27. Clements ME, Johnson RW. PREX1 drives spontaneous bone dissemination of ER+ breast cancer cells. Oncogene 2020;39:1318-34. DOI PubMed PMC

28. Ottewell PD, Wang N, Brown HK, et al. Zoledronic acid has differential antitumor activity in the pre- and postmenopausal bone microenvironment in vivo. Clin Cancer Res 2014;20:2922-32. DOI PubMed PMC

29. Bord S, Horner A, Beavan S, Compston J. Estrogen receptors alpha and beta are differentially expressed in developing human bone. $J$ Clin Endocrinol Metab 2001;86:2309-14. DOI PubMed

30. Braidman IP, Hainey L, Batra G, Selby PL, Saunders PT, Hoyland JA. Localization of estrogen receptor beta protein expression in adult human bone. J Bone Miner Res 2001;16:214-20. DOI PubMed

31. Rooney AM, van der Meulen MCH. Mouse models to evaluate the role of estrogen receptor $\alpha$ in skeletal maintenance and adaptation. Ann N Y Acad Sci 2017;1410:85-92. DOI PubMed

32. Manolagas SC, O'Brien CA, Almeida M. The role of estrogen and androgen receptors in bone health and disease. Nat Rev Endocrinol 2013;9:699-712. DOI PubMed PMC

33. Khosla S, Monroe DG. Regulation of bone metabolism by sex steroids. Cold Spring Harb Perspect Med 2018;8:a031211. DOI PubMed PMC

34. Cheng JN, Frye JB, Whitman SA, Funk JL. Skeletal impact of 17ß-estradiol in T cell-deficient mice: age-dependent bone effects and osteosarcoma formation. Clin Exp Metastasis 2020;37:269-81. DOI PubMed PMC

35. Winding B, Misander H, Høegh-andersen P, Brünner N, Tækker Foged N. Estradiol enhances osteolytic lesions in mice inoculated with human estrogen receptor-negative MDA-231 breast cancer cells in vivo. Breast Cancer Res Treat 2003;78:205-16. DOI PubMed

36. Cohen DJ, Patel V, Verma A, Boyan BD, Schwartz Z. Effect of 17ß-estradiol on estrogen receptor negative breast cancer cells in an osteolytic mouse model. Steroids 2019;142:28-33. DOI PubMed

37. Ottewell PD, Wang N, Brown HK, et al. OPG-Fc inhibits ovariectomy-induced growth of disseminated breast cancer cells in bone. Int J Cancer 2015;137:968-77. DOI PubMed

38. Wang W, Belosay A, Yang X, et al. Effects of letrozole on breast cancer micro-metastatic tumor growth in bone and lung in mice inoculated with murine 4T1 cells. Clin Exp Metastasis 2016;33:475-85. DOI PubMed

39. Price TT, Burness ML, Sivan A, et al. Dormant breast cancer micrometastases reside in specific bone marrow niches that regulate their transit to and from bone. Sci Transl Med 2016;8:340ra73. DOI PubMed

40. Wang H, Yu C, Gao X, et al. The osteogenic niche promotes early-stage bone colonization of disseminated breast cancer cells. Cancer Cell 2015;27:193-210. DOI PubMed PMC

41. Wright LE, Frye JB, Lukefahr AL, et al. Curcuminoids block TGF- $\beta$ signaling in human breast cancer cells and limit osteolysis in a murine model of breast cancer bone metastasis. J Nat Prod 2013;76:316-21. DOI PubMed PMC

42. Guise TA, Yin JJ, Taylor SD, et al. Evidence for a causal role of parathyroid hormone-related protein in the pathogenesis of human breast cancer-mediated osteolysis. J Clin Invest 1996;98:1544-9. DOI PubMed PMC

43. Kunihiro AG, Brickey JA, Frye JB, Luis PB, Schneider C, Funk JL. Curcumin, but not curcumin-glucuronide, inhibits Smad signaling 
in TGF $\beta$-dependent bone metastatic breast cancer cells and is enriched in bone compared to other tissues. J Nutr Biochem 2019;63:150-6. DOI PubMed PMC

44. Faul F, Erdfelder E, Lang AG, Buchner A. G*Power 3: a flexible statistical power analysis program for the social, behavioral, and biomedical sciences. Behav Res Methods 2007:39:175-91. DOI PubMed

45. Pearse G, Frith J, Randall KJ, Klinowska T. Urinary retention and cystitis associated with subcutaneous estradiol pellets in female nude mice. Toxicol Pathol 2009;37:227-34. DOI PubMed

46. Gakhar G, Wight-Carter M, Andrews G, Olson S, Nguyen TA. Hydronephrosis and urine retention in estrogen-implanted athymic nude mice. Vet Pathol 2009;46:505-8. DOI PubMed

47. Wright LE, Frye JB, Timmermann BN, Funk JL. Protection of trabecular bone in ovariectomized rats by turmeric (Curcuma longa L.) is dependent on extract composition. J Agric Food Chem 2010;58:9498-504. DOI PubMed PMC

48. Funk JL, Cordaro LA, Wei H, Benjamin JB, Yocum DE. Synovium as a source of increased amino-terminal parathyroid hormonerelated protein expression in rheumatoid arthritis. A possible role for locally produced parathyroid hormone-related protein in the pathogenesis of rheumatoid arthritis. J Clin Invest 1998;101:1362-71. DOI PubMed PMC

49. Dempster DW, Compston JE, Drezner MK, et al. Standardized nomenclature, symbols, and units for bone histomorphometry: a 2012 update of the report of the ASBMR Histomorphometry Nomenclature Committee. J Bone Miner Res 2013;28:2-17. DOI PubMed PMC

50. Haider MT, Holen I, Dear TN, Hunter K, Brown HK. Modifying the osteoblastic niche with zoledronic acid in vivo-potential implications for breast cancer bone metastasis. Bone 2014;66:240-50. DOI PubMed PMC

51. Streicher C, Heyny A, Andrukhova O, et al. Estrogen regulates bone turnover by targeting RANKL expression in bone lining cells. Sci Rep 2017;7:6460. DOI PubMed PMC

52. Florencio-Silva R, Sasso GR, Sasso-Cerri E, Simões MJ, Cerri PS. Biology of bone tissue: structure, function, and factors that influence bone cells. Biomed Res Int 2015;2015:421746. DOI PubMed PMC

53. Brown HK, Ottewell PD, Evans CA, Holen I. Location matters: osteoblast and osteoclast distribution is modified by the presence and proximity to breast cancer cells in vivo. Clin Exp Metastasis 2012;29:927-38. DOI PubMed

54. Meng X, Vander Ark A, Lee P, et al. Myeloid-specific TGF- $\beta$ signaling in bone promotes basic-FGF and breast cancer bone metastasis. Oncogene 2016;35:2370-8. DOI PubMed

55. Biswas S, Nyman JS, Alvarez J, et al. Anti-transforming growth factor $\beta$ antibody treatment rescues bone loss and prevents breast cancer metastasis to bone. PLoS One 2011;6:e27090. DOI PubMed PMC

56. Haisenleder DJ, Schoenfelder AH, Marcinko ES, Geddis LM, Marshall JC. Estimation of estradiol in mouse serum samples: evaluation of commercial estradiol immunoassays. Endocrinology 2011;152:4443-7. DOI PubMed PMC

57. Bouxsein ML, Myers KS, Shultz KL, Donahue LR, Rosen CJ, Beamer WG. Ovariectomy-induced bone loss varies among inbred strains of mice. J Bone Miner Res 2005;20:1085-92. DOI PubMed

58. Gérard C, Mestdagt M, Tskitishvili E, et al. Combined estrogenic and anti-estrogenic properties of estetrol on breast cancer may provide a safe therapeutic window for the treatment of menopausal symptoms. Oncotarget 2015;6:17621-36. DOI PubMed PMC

59. Wright LE, Ottewell PD, Rucci N, et al. Murine models of breast cancer bone metastasis. Bonekey Rep 2016;5:804. DOI PubMed PMC

60. Khosla S, Oursler MJ, Monroe DG. Estrogen and the skeleton. Trends Endocrinol Metab 2012;23:576-81. DOI PubMed PMC

61. Fantozzi A, Christofori G. Mouse models of breast cancer metastasis. Breast Cancer Res 2006;8:212. DOI PubMed PMC

62. Powell GJ, Southby J, Danks JA, et al. Localization of parathyroid hormone-related protein in breast cancer metastases: increased incidence in bone compared with other sites. Cancer Res 1991;51:3059-61. PubMed

63. Southby J, Kissin MW, Danks JA, et al. Immunohistochemical localization of parathyroid hormone-related protein in human breast cancer. Cancer Res 1990;50:7710-6. PubMed

64. Sun J, Huang YR, Harrington WR, Sheng S, Katzenellenbogen JA, Katzenellenbogen BS. Antagonists selective for estrogen receptor alpha. Endocrinology 2002;143:941-7. DOI PubMed

65. Kraichely DM, Sun J, Katzenellenbogen JA, Katzenellenbogen BS. Conformational changes and coactivator recruitment by novel ligands for estrogen receptor-alpha and estrogen receptor-beta: correlations with biological character and distinct differences among SRC coactivator family members. Endocrinology 2000;141:3534-45. DOI PubMed

66. Li S, Peng Y, Weinhandl ED, et al. Estimated number of prevalent cases of metastatic bone disease in the US adult population. Clin Epidemiol 2012;4:87-93. DOI PubMed PMC

67. Mundy GR. Metastasis: metastasis to bone: causes, consequences and therapeutic opportunities. Nat Rev Cancer 2002;2:584-93. DOI PubMed

68. Svendsen H, Gammelager H, Sværke C, et al. Hospital visits among women with skeletal-related events secondary to breast cancer and bone metastases: a nationwide population-based cohort study in Denmark. Clin Epidemiol 2013;5:97. DOI PubMed PMC

69. Haque R, Ahmed SA, Inzhakova G, et al. Impact of breast cancer subtypes and treatment on survival: an analysis spanning two decades. Cancer Epidemiol Biomarkers Prev 2012;21:1848-55. DOI PubMed PMC

70. Colzani E, Johansson ALV, Liljegren A, et al. Time-dependent risk of developing distant metastasis in breast cancer patients according to treatment, age and tumour characteristics. Br J Cancer 2014;110:1378-84. DOI PubMed PMC

71. Turner NC, Neven P, Loibl S, Andre F. Advances in the treatment of advanced oestrogen-receptor-positive breast cancer. Lancet 2017;389:2403-14. DOI PubMed

72. Portman N, Alexandrou S, Carson E, Wang S, Lim E, Caldon CE. Overcoming CDK4/6 inhibitor resistance in ER-positive breast cancer. Endocr Relat Cancer 2019;26:R15-30. DOI PubMed 
73. Yoneda T, Williams PJ, Hiraga T, Niewolna M, Nishimura R. A bone-seeking clone exhibits different biological properties from the MDA-MB-231 parental human breast cancer cells and a brain-seeking clone in vivo and in vitro. J Bone Miner Res 2001;16:1486-95. DOI PubMed

74. Funk JL, Wei H. Regulation of parathyroid hormone-related protein expression in MCF-7 breast carcinoma cells by estrogen and antiestrogens. Biochem Biophys Res Commun 1998;251:849-54. DOI PubMed

75. Black DM, Rosen CJ. Clinical practice: postmenopausal osteoporosis. N Engl J Med 2016;374:254-62. DOI PubMed

76. Cancer Stat Facts: Female Breast Cancer Subtypes. Natl Cancer Inst Surveillance, Epidemiol End Results Progr n.d. https://seer.cancer.gov/statfacts/html/breast-subtypes.html. [Last accessed on 30 Mar 2021].

77. Braun S, Vogl FD, Naume B, et al. A pooled analysis of bone marrow micrometastasis in breast cancer. N Engl J Med 2005;353:793802. DOI PubMed

78. Braun S, Auer D, Marth C. The prognostic impact of bone marrow micrometastases in women with breast cancer. Cancer Invest 2009;27:598-603. DOI PubMed

79. Hussein O, Komarova SV. Breast cancer at bone metastatic sites: recent discoveries and treatment targets. J Cell Commun Signal 2011;5:85-99. DOI PubMed PMC

80. Falck AK, Bendahl PO, Ingvar C, et al. Analysis of and prognostic information from disseminated tumour cells in bone marrow in primary breast cancer: a prospective observational study. BMC Cancer 2012;12:403. DOI PubMed PMC

81. Brown HK, Allocca G, Ottewell PD, et al. Parathyroid hormone (PTH) increases skeletal tumour growth and alters tumour distribution in an in vivo model of breast cancer. Int J Mol Sci 2018;19:2920. DOI PubMed PMC

82. Swami S, Johnson J, Bettinson LA, et al. Prevention of breast cancer skeletal metastases with parathyroid hormone. JCI Insight 2017;2:90874. DOI PubMed PMC

83. Jiang G, Zhang S, Yazdanparast A, et al. Comprehensive comparison of molecular portraits between cell lines and tumors in breast cancer. BMC Genomics 2016;17:525. DOI PubMed PMC

84. Sasaki A, Boyce BF, Story B, et al. Bisphosphonate risedronate reduces metastatic human breast cancer burden in bone in nude mice. Cancer Res 1995;55:3551-7. PubMed

85. Holen I, Speirs V, Morrissey B, Blyth K. In vivo models in breast cancer research: progress, challenges and future directions. Dis Model Mech 2017;10:359-71. DOI PubMed PMC

86. Murayama T, Gotoh N. Patient-derived Xenograft models of breast cancer and their application. Cells 2019;8:621. DOI PubMed PMC

87. Dobrolecki LE, Airhart SD, Alferez DG, et al. Patient-derived xenograft (PDX) models in basic and translational breast cancer research. Cancer Metastasis Rev 2016;35:547-73. DOI PubMed PMC

88. Matthews SB, Sartorius CA. Steroid hormone receptor positive breast cancer patient-derived Xenografts. Horm Cancer 2017;8:4-15. DOI PubMed PMC

89. Yin JJ, Mohammad KS, Käkönen SM, et al. A causal role for endothelin-1 in the pathogenesis of osteoblastic bone metastases. Proc Natl Acad Sci U S A 2003;100:10954-9. DOI PubMed PMC 